J. Dairy Sci. 95:3987-3996

http://dx.doi.org/10.3168/jds.2011-5104

(C) American Dairy Science Association ${ }^{\circledR}, 2012$.

\title{
Estimate of colostral immunoglobulin G concentration using refractometry without or with caprylic acid fractionation
}

\author{
K. M. Morrill, ${ }^{\star 1}$ E. Conrad, $\dagger$ J. Polo, $\neq$ A. Lago, $\neq^{2}$ J. Campbell, $\ddagger$ J. Quigley, $† \ddagger^{3}$ and H. Tyler† \\ ${ }^{*}$ Cornell Cooperative Extension, Cornell University, Ithaca, NY14853 \\ †Department of Animal Science, lowa State University, Ames 50014 \\ ¥APC Inc., Ankeny, IA 50021
}

\section{ABSTRACT}

Our objectives were to evaluate the use of refractometry as a means of estimating immunoglobulin $\mathrm{G}(\operatorname{Ig} \mathrm{G})$ concentration of bovine maternal colostrum (MC) and determine if fractionation of MC using caprylic acid (CA) improved estimates of IgG. Samples $(\mathrm{n}=85)$ of $\mathrm{MC}$ were collected from a single dairy in California and used to determine the method of CA fraction that produced the best prediction of $\mathrm{IgG}$ based on CA fractionation followed by refractometry. Subsequently, samples of MC $(\mathrm{n}=827)$ were collected from 67 farms in 12 states to compare refractometry with or without CA fractionation as methods to estimate IgG concentration. Samples were collected from the feeding pool and consisted of fresh $(\mathrm{n}=196)$, previously frozen (n $=479)$, or refrigerated $(\mathrm{n}=152)$ MC. Samples were further classified by the number freeze-thaw cycles before analysis. Fractionation with $\mathrm{CA}$ was conducted by adding $1 \mathrm{~mL}$ of $\mathrm{MC}$ to a tube containing $75 \mu \mathrm{L}$ of $\mathrm{CA}$ and $1 \mathrm{~mL}$ of $0.06 \mathrm{M}$ acetic acid. The tube was shaken and allowed to react for $1 \mathrm{~min}$. Refractive index of the IgG-rich supernatant (nDf) was determined using a digital refractometer. Whole, nonfractionated MC was analyzed for IgG by radial immunodiffusion (RID) and refractive index $(\mathrm{nDw})$. The relationship between $\mathrm{nDf}$ and $\operatorname{IgG}(\mathrm{r}=0.53 ; \mathrm{n}=805)$ was weak, whereas that between $\mathrm{nDw}$ and $\mathrm{IgG}$ was stronger $(\mathrm{r}=0.73 ; \mathrm{n}=823)$. Fresh samples analyzed by refractometry that subsequently went through 1 freeze-thaw cycle before RID analysis resulted in the strongest relationship between IgG and $\mathrm{nDf}$ or $\mathrm{nDw}(\mathrm{r}=0.93$ and 0.90 , respectively). The MC samples collected fresh on the farm but frozen 2 or more times before analysis by refractometry or RID had low correlations between IgG and $\mathrm{nDf}$ and $\mathrm{nDw}(\mathrm{r}$ $=0.09$ and 0.01). Samples refrigerated or frozen on the

Received October 28, 2011.

Accepted February 28, 2012.

${ }^{1}$ Corresponding author: kmm434@cornell.edu

${ }^{2}$ Current address: Dairy Experts, Tulare, CA 93274.

${ }^{3}$ Current address: Provimi North America, Brookville, OH 45309. farm before analysis had weaker relationships between $\mathrm{RID}$ and $\mathrm{nDf}$ or $\mathrm{nDw}(\mathrm{r}=0.38$ to 0.80$)$, regardless of the number of freeze-thaw cycles. Breed and lactation number did not affect the accuracy of either test. These results indicated that refractometry, without or with CA fractionation, was an accurate and rapid method to determine $\mathrm{IgG}$ concentration when samples of $\mathrm{MC}$ were not previously stored before refractometry and frozen only once before RID analysis.

Key words: colostrum, refractometer, passive transfer, immunoglobulin G

\section{INTRODUCTION}

Newborn calves are born agammaglobulinemic, without any measurable circulating IgG or IgM. The newborn calf derives passive immunity by absorbing immunoglobulins from colostrum (Smith et al., 1964). Passive immunity can be both local (immunoglobulins bathing the gut lumen) and humoral (immunoglobulins absorbed from the gut into the blood; Lecce, 1984). In the calf, passively acquired immunity is the primary factor affecting the health of the calf until they are capable of endogenous synthesis of antibodies (Smith, 1948). Neonates that obtain passive transfer postpartum are able to absorb large protein molecules across the small intestinal epithelium without prior digestion or alteration of the molecules for a short period postpartum. Nonselective transport occurs by vesicular transport of macromolecules that adhere to the surface membrane or are transported in the fluid-phase compartment of the vesicles (Pácha, 2000). The absorptive process in calves is primarily nonselective, and a wide variety of macromolecules can be absorbed through the gut into the blood (Lecce, 1972).

Successful transfer of passive immunity (serum IgG $>10 \mathrm{mg} / \mathrm{mL}$ ) can be determined by measuring the concentration of IgG in the serum of the calf at 24 to $48 \mathrm{~h}$ after birth. Primary factors that influence the acquisition of passive immunity include the volume of quality maternal colostrum (MC) fed (Stott and Fellah, 1983; Jaster, 2005), the immunoglobulin concentration, and 
the time elapsed postpartum before feeding (Nocek et al., 1984). Colostrum samples $(\mathrm{n}=1,250)$ from Norwegian Red cattle had IgG concentrations ranging from 4 to $235 \mathrm{~g} / \mathrm{L}$. Concentration of IgG was inadequate in $57.8 \%$ of the samples. Cluster effects within the herd explained $13.7 \%$ of variation in MC quality (Gulliksen et al., 2008). Immunoglobulin $\mathrm{G}$ concentration and nutrient composition of $\mathrm{MC}$ changes throughout the first 6 milkings postpartum (Foley and Otterby, 1978) and can be influenced by breed, parity (Muller and Ellinger, 1981; Kume and Tanabe, 1993; Gulliksen et al., 2008), dry period length, time of milking postpartum, and individual farm (Gulliksen et al., 2008).

Thus, a rapid, accurate, and inexpensive method to estimate $\operatorname{IgG}$ concentration in MC is essential for identification of quality MC. Laboratory methods to accurately measure IgG concentration are too complex and expensive for routine use on farm. Currently, only $13 \%$ of all US dairy operations evaluate MC quality before feeding (NAHMS, 2007), although farms with a herd size $\geq 500$ are more likely to evaluate MC quality (45.2\%) compared with farms with $<100$ head (7.6\%). The most common methods used by farms that measure MC quality were the use of a colostrometer and assessing the visual appearance (43.7 and $41.6 \%$ of farms, respectively). Volume of colostrum and other methods comprise the remaining $14.7 \%$ (NAHMS, 2007). Colostrometers estimate total globulin concentration based on measurement of specific gravity (Fleenor and Stott, 1980). The colostrometer is not an analytical technique, but rather a method that can be utilized to estimate relative quality of MC. Although colostrometers have allowed producers to identify poor or quality MC, they are often inaccurate (Morin et al., 2001). The quality readings on the colostrometer are based on the specific gravity of normal milk and provide an estimate of relative quality, not IgG quantity (Fleenor and Stott, 1980; Quigley et al., 1994). Colostral specific gravity can be affected by breed, month of calving and parity (Morin et al., 2001). Colostrometer readings are affected by temperature of the MC and TS content (Mechor et al., 1992; Morin et al., 2001).

Refractometers, digital or optical, measure total protein (TP) in MC and calf serum (Calloway et al., 2002; Moore et al., 2009; Bielmann et al., 2010). Protein solutions refract light, and refractometers use this property to estimate TP in a solution (Chavatte, et al., 1998). Most of the protein in MC is IgG; thus, measuring TP in MC may provide a value that is highly correlated with IgG concentration. Although knowing the TP content of MC is valuable, the actual $\mathrm{IgG}$ concentration is of more value to the dairy farmer than the TP content, because adjustments in volume of $\mathrm{MC}$ fed can be made to ensure adequate intake of IgG.
Caprylic acid (CA) precipitates non-IgG proteins, leaving the $\operatorname{IgG}$ in the supernatant. A combination of $\mathrm{CA}$ and ammonium sulfate improves yield and purification of some proteins (Bergmann-Leitner et al., 2008; Grodzki and Berenstein, 2010). When CA is added to lacteal secretions during the dry period, most proteins are precipitated and IgG may be accurately measured in the supernatant (Guidry and O'Brien, 1996).

Objectives of this study were to (1) develop and validate an on-farm method of fractionation of $\mathrm{MC}$ using CA followed by refractometry, (2) compare refractometry of whole $\mathrm{MC}$, without or with prior $\mathrm{CA}$ fractionation, as a means of estimating IgG in MC, and (3) determine if methods are affected by breed, parity, storage method, nutrient composition or bacterial contamination.

\section{MATERIALS AND METHODS}

\section{Development of CA Fractionation Method}

Samples of bovine MC were collected from the first milking after calving from Holstein dairy cattle (n $=85$ ) on one California dairy. Samples were frozen, placed on dry ice, and shipped to Iowa State University (Ames). All samples arrived frozen and were placed in a $-20^{\circ} \mathrm{C}$ manual defrost freezer until further analysis. Colostrum samples were thawed in a warm water bath and brought to room temperature $\left(20^{\circ} \mathrm{C}\right)$. All samples were analyzed within $4 \mathrm{~h}$ of thawing. Fifty-five of the 85 samples were analyzed to determine the optimal procedure for CA precipitation. Thirty of the original $85 \mathrm{MC}$ samples were analyzed to determine the optimal reaction time once the optimal concentrations of $\mathrm{CA}$ and acetic acid were determined.

One milliliter of $\mathrm{MC}$ was added to a tube containing $1.5 \mathrm{~mL}$ of $0.06 \mathrm{M}$ acetic acid and $75 \mu \mathrm{L}$ of CA. Samples were mixed for $10 \mathrm{~s}$ and allowed to react for $0,1,3$, $5,10,15,20,25,30,45$, or $60 \mathrm{~min}$ before analysis of the supernatant. The supernatant was analyzed using a digital refractometer (model 300034, SPER Scientific, Scottsdale, AZ). Additional samples were analyzed for incubation times of $1,3,5$, and 10 min to confirm the findings from the initial data.

\section{On-Farm Evaluation of Refractometry of MC}

Dairy farms $(\mathrm{n}=67)$ in 12 states participated in the study between June and October 2010. Participating farms were required to feed MC that was not supplemented with commercial colostrum supplements nor pasteurized. Managers also were required to complete 2 management surveys. Farms ranged from 70 to $>5,000$ lactating dairy cows. 


\section{Colostrum Sample Collection}

Samples of MC were collected based on the MC that was currently available in the feeding pool at the time of the site visit. Colostrum that was discarded after milking and never entered the feeding pool was not sampled. Samples of frozen, refrigerated, and fresh $\mathrm{MC}$ were obtained. The MC was from individual cows or from multiple cow pools according to the normal management of the farm. Thus, samples obtained reflected MC that was available to feed calves and was not intended to reflect the quality of all $\mathrm{MC}$ that was harvested from cows.

A 50-mL sample of $\mathrm{MC}$ was collected using a sterile dipper and divided into 3 sample vials. Two were frozen $\left(-20^{\circ} \mathrm{C}\right)$, placed on dry ice, and shipped to the appropriate laboratory for analysis of IgG, nutrient composition, and bacterial contamination. The third sample was analyzed for refractive index of fractionated and whole MC. Samples were classified based on storage method of the MC before feeding: fresh = no storage, refrigerated $=$ stored in a refrigerator, or frozen $=$ stored in a freezer. Information, including whether the sample was from an individual cow or pool, breed, lactation number, and number of times the sample was frozen before analysis, were recorded for each sample. Samples representing lactations 3 and greater were combined into one group. Information regarding storage time before sample collection and internal temperature of on-farm refrigerator or freezer were not collected for this study.

\section{CA Test Fractionation}

One milliliter of $\mathrm{MC}$ was added to a tube containing $1.5 \mathrm{~mL}$ of $0.06 \mathrm{M}$ acetic acid and $75 \mu \mathrm{L}$ of CA. Samples were mixed for $10 \mathrm{~s}$ and allowed to react for 60 s. A sample of the supernatant was analyzed using the digital refractometer.

\section{Refractometer Readings}

Approximately $50 \mu \mathrm{L}$ of whole $\mathrm{MC}$ or CA supernatant was placed on a refractometer prism (SPER Scientific), and refractive index $(\mathbf{n D})$ readings and \%Brix (sugar content) were recorded. The $\mathrm{nD}$ is the refractive index of a solution measured at the wavelength of the sodium D line $(589.3 \mathrm{~nm})$ at $20^{\circ} \mathrm{C}$. The $\%$ Brix value can be obtained from the polynomial fit to the ICUMSA (2009) table: Brix $=(\{[(11,758.74 \times \mathrm{nD}-88,885.21) \times \mathrm{nD}+$ $270,177.93] \times \mathrm{nD}-413,145.80\} \times \mathrm{nD}+318,417.95)$ $\times \mathrm{nD}-99,127.4536$. The refractometer was calibrated with distilled water at the start of each set of analyses.

\section{Radial Immunodiffusion Analysis}

Colostrum samples were thawed in a warm water bath and thoroughly mixed before radial immunodiffusion (RID) analysis. One milliliter of MC was added to $3 \mathrm{~mL}$ of distilled water and mixed well. Five microliters of diluted colostrum solution was added to each well of a bovine IgG RID test plate (Triple J Farms, Bellingham, WA). Radial immunodiffusion plates were incubated for $24 \mathrm{~h}$ and the diameter of precipitin ring was measured. The diameter of the precipitin ring was compared with a standard curve created by the internal test standards to determine IgG concentration. All samples were run in duplicate. Samples with a precipitin ring greater than that of the highest internal standard $(26.25 \mathrm{mg} / \mathrm{mL})$ were further diluted and reanalyzed. Samples with a precipitin ring smaller than that of the lowest internal standard $(1.84 \mathrm{mg} / \mathrm{mL})$ were re-analyzed in an undiluted form.

\section{Nutrient and Bacterial Analysis}

Fat, protein, lactose, TS, and other solids were analyzed on a Foss Milkoscan FT+, and SCC was analyzed on a Fossomatic FC (Foss Electric, Hillerød, Denmark). Total bacterial plate counts were performed with the Petrifilm plate loop count method (section 6.030; Wehr, 2004). Coliform counts were performed with the Petrifilm coliform count plate method (section 7.071; Wehr, 2004).

\section{Statistical Analysis}

The Univariate procedure of SAS (SAS Institute Inc., Cary, NC) was used to determine the frequency of observations and outlier samples to be removed from the data set. The Proc Corr procedure of SAS (SAS Institute Inc.) was used to determine the relationship between the $\mathrm{nD}$ of $\mathrm{CA}$ test supernatant, whole $\mathrm{MC}$ to IgG concentration, TS, other solids, protein, fat, SCC, total bacterial plate count, and coliform count. Using the $\mathrm{nD}$ measurement from the $\mathrm{CA}$ test or whole $\mathrm{MC}$ and the correlation to RID-obtained IgG concentrations, regression equations were developed to estimate the IgG concentration from the $\mathrm{nD}$ of the CA test and whole MC based on the storage method.

The Proc GLM procedure (SAS Institute Inc.) was used to determine differences in nutrient composition based on the number of freeze-thaw (FT) cycles within a storage method according to the model

$$
Y_{i j}=\mu+F_{i}+e_{i j}
$$


Table 1. Correlation coefficients between $\operatorname{IgG}$ concentration and Brix or refractive index $(\mathrm{nD})$ refractometer readings for trial 3

\begin{tabular}{|c|c|c|c|c|c|}
\hline \multirow{2}{*}{$\begin{array}{l}\text { Incubation } \\
\text { time (min) }\end{array}$} & \multirow{2}{*}{$\begin{array}{c}\text { Samples } \\
\text { (no.) }\end{array}$} & \multicolumn{2}{|c|}{$\operatorname{IgG} \times$ Brix } & \multicolumn{2}{|c|}{$\mathrm{IgG} \times \mathrm{nD}$} \\
\hline & & $\mathrm{r}$ & $P$-value & $\mathrm{r}$ & $P$-value \\
\hline 0 & 10 & 0.63 & 0.049 & 0.68 & 0.0293 \\
\hline 1 & 30 & 0.96 & $<0.0001$ & 0.95 & $<0.0001$ \\
\hline 3 & 20 & 0.96 & $<0.0001$ & 0.96 & $<0.0001$ \\
\hline 5 & 30 & 0.95 & $<0.0001$ & 0.95 & $<0.0001$ \\
\hline 10 & 30 & 0.94 & $<0.0001$ & 0.94 & $<0.0001$ \\
\hline 15 & 10 & 0.95 & $<0.0001$ & 0.95 & $<0.0001$ \\
\hline 20 & 10 & 0.91 & 0.0002 & 0.91 & 0.0003 \\
\hline 25 & 10 & 0.81 & 0.0045 & 0.82 & 0.003 \\
\hline 30 & 10 & 0.95 & $<0.0001$ & 0.95 & $<0.0001$ \\
\hline 45 & 10 & 0.95 & $<0.0001$ & 0.94 & $<0.0001$ \\
\hline 60 & 10 & 0.92 & 0.0002 & 0.92 & 0.0002 \\
\hline
\end{tabular}

where $Y_{i j}=$ the dependent variable; $\mu=$ the overall mean; $F_{i}=$ the fixed effect of the $i$ th storage level; and $e_{i j}=$ the residual error.

For GLM models, least squares means were determined for each storage method before sample collection. The PDIFF option (SAS Institute Inc.) was used to separate least squares means among storage methods; significance was declared at $P \leq 0.05$.

Epidemiological diagnostic test characteristics (sensitivity, specificity, and predictive values) were calculated to compare the digital refractometer $\mathrm{nD}$ to RID (the current industry standard). Sensitivity was defined as the probability of a test result (refractometer $\mathrm{nD}$ ) indicative of an inadequate colostral IgG concentration for a sample with an IgG concentration greater than 50 $\mathrm{mg} / \mathrm{mL}$ as determined by RID. Specificity was defined as the probability of a test result (refractometer $\mathrm{nD}$ ) indicative of an adequate colostral IgG concentration for a sample with an IgG concentration less than 50 $\mathrm{mg} / \mathrm{mL}$ as determined by RID. Positive and negative predictive values were calculated using the prevalence of samples with an RID IgG concentration of greater than or less than $50 \mathrm{mg} / \mathrm{mL}$ and an $\mathrm{nD}$ reading above or below the cut point, respectively. The Fisher's exact method was used to determine differences among breeds, lactation, and storage method.

\section{RESULTS}

\section{Development of the CA Fractionation Method}

Mean IgG concentration for MC was $58.9 \mathrm{mg} / \mathrm{mL}$ (SD $=33.3$ ) with a range from 2 to $116 \mathrm{mg} / \mathrm{mL}$. Incubation times of $1,3,5,10,15,20,30,45$, and 60 min before analysis of supernatant all provided a correlation coefficient $>0.90$ (Table 1), whereas analyzing the sample immediately resulted in a weaker relationship between refractive index $(\mathrm{nD})$ and $\operatorname{IgG}$ concentration $(\mathrm{r}=0.60$;
$P=0.029)$. The relationship between $\mathrm{nD}$ and $\operatorname{IgG} \operatorname{did}$ not change when 10 or more samples were analyzed for incubation times of $1,3,5$, or $10 \mathrm{~min}$.

\section{On-Farm Evaluation of Refractometry of MC}

In total, $827 \mathrm{MC}$ samples were analyzed (Table 2). Most samples were from Holstein cattle $(\mathrm{n}=494)$, were frozen on the farm before entering the feeding pool (n $=479$ ), and were collected in the southwestern region of the United States $(\mathrm{n}=410)$. Breed and lactation data were not recorded if samples were from colostral pools or if the farm could not provide the information.

The IgG concentration and $\mathrm{nD}$ values of fractionated (nDf) and whole (nDw) MC are reported in Table 3. Overall mean IgG concentration was $69.3 \mathrm{mg} / \mathrm{mL}$ $(\mathrm{SD}=32.8)$. The $\mathrm{nDf}$ ranged from 1.3374 to 1.3612 , with a mean of $1.34424(\mathrm{SD}=0.00395)$, whereas $\mathrm{nDw}$ ranged from 1.3425 to 1.3912 , with a mean of 1.36604 $(\mathrm{SD}=0.00804)$. No differences in $\mathrm{nDf}$ or $\mathrm{nDw}$ were observed across breed or lactation; however, samples frozen before collection had higher $\mathrm{nDf}$ compared with fresh or refrigerated samples $(P<0.05)$. The $\mathrm{nDw}$ of frozen samples were similar to that of fresh samples, but higher than that of refrigerated samples $(P<0.05)$. Overall nutrient composition and bacterial contamination are given in Table 4 .

\section{Correlation of $n D$ with $\lg G$}

The IgG concentration of MC was weakly correlated with $\mathrm{nDf}$ when all samples were evaluated $(\mathrm{n}=805 ; \mathrm{r}$ $=0.53, P<0.0001)$. A higher correlation between IgG and $\mathrm{nDw}$ was observed $(\mathrm{n}=823 ; \mathrm{r}=0.73, P<0.0001)$. Classifying MC samples by storage method before collection (Table 5) indicated that fresh samples had the strongest relationship between $\mathrm{nD}$ and $\mathrm{IgG}$ concentra- 
Table 2. Colostrum samples collected across region, state, breed, lactation, and storage method

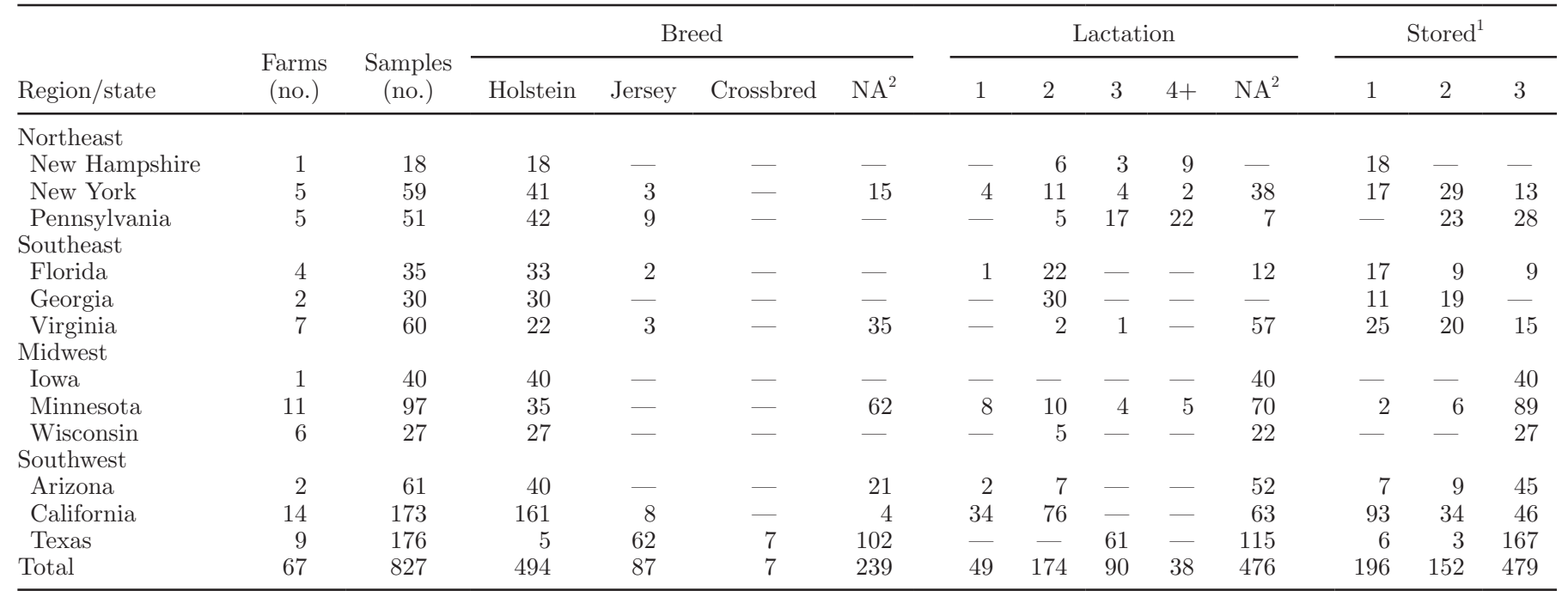

${ }^{1}$ Location where colostrum was stored before sampling: $1=$ fresh/not stored, $2=$ refrigerator, $3=$ freezer.

${ }^{2}$ Breed and lactation information were not available if samples were pooled before collection.

tion, regardless of whether $\mathrm{nD}$ was measured on whole $\mathrm{MC}$ or following $\mathrm{CA}$ fractionation.

Method of on-farm storage and the number of times a sample was frozen before analysis affected the relationship between IgG and nD. Samples collected fresh (not refrigerated or frozen) and not frozen before analysis of $\mathrm{nDf}$ and $\mathrm{nDw}$ had the greatest correlation with $\mathrm{IgG}$ $(\mathrm{r}=0.93$ and 0.90 , respectively). The correlation with IgG was poor when fresh $\mathrm{MC}$ was frozen once $(\mathrm{nDw})$ or twice (nDf) (Table 6). The $\mathrm{nD}$ of refrigerated and frozen samples were less well correlated with IgG compared with those of fresh samples. Multiple FT cycles before analysis of $\mathrm{nD}$ or $\mathrm{IgG}$ appeared to reduce predictability of $\mathrm{nD}$ to $\mathrm{IgG}$, particularly when samples were frozen and thawed twice before measurement of $\mathrm{nDf}$ or $\operatorname{IgG}$ or once before measurement of $\mathrm{nDw}$ (Table 7). The relationships between $\mathrm{IgG}$ and $\mathrm{nDf}$ or $\mathrm{nDw}$ were not affected by nutrient content or bacterial contamination (data not shown) of the MC.

\section{Diagnostic Test Characteristics}

Diagnostic test characteristics for both refractometry methods using all samples are in Table 8. We predicted a cut-point of $50 \mathrm{mg} / \mathrm{mL}$ of $\mathrm{MC}$ based on regression of $\mathrm{nD}$ estimates and IgG. Then, sensitivity, specificity, positive predictive value and negative predictive values were calculated. Sensitivity of predictions using $\mathrm{nDf}$ or $\mathrm{nDw}$ was high across all storage groups. Specificity and positive predictive value increased when fresh samples (without multiple FT cycles) were analyzed (Table 9).

\section{DISCUSSION}

These data represent MC available on selected farms from June through October 2010. The data do not necessarily represent all MC produced but, more importantly, they do reflect the MC that is eventually fed to calves. Storage method was referred to where the MC was stored before collection; it does not indicate the temperature or length of storage. Samples were collected only from dairies that did not pasteurize or add preservatives or supplements to MC; additionally, managers or herd owners had to be willing to complete a management survey for an additional study.

Providing a tool for producers to rapidly and accurately estimate the concentration of IgG in MC could improve the health of calves and the profitability of producers. Refractometry following CA fractionation was strongly correlated with IgG in the laboratory. This relationship was not as strong within the overall on-farm data set. Normal variation in on-farm colostrum management reduced the accuracy and precision of refractometry. Colostrum storage method strongly affected prediction of IgG by refractometry, though breed and lactation number had little effect.

Refractometry of whole MC can provide a reasonable estimation $\left(\mathrm{R}^{2}=0.79\right)$ of IgG concentration (Molla, 1980). Measurement of Brix with optical and digital refractometers correlated $(\mathrm{r}=0.71$ and $\mathrm{r}=0.74)$ with IgG concentration (Bielmann et al., 2010). Chigerwe et al. (2008) reported slightly lower correlation coefficients $(\mathrm{r}=0.62, \mathrm{n}=171)$. 


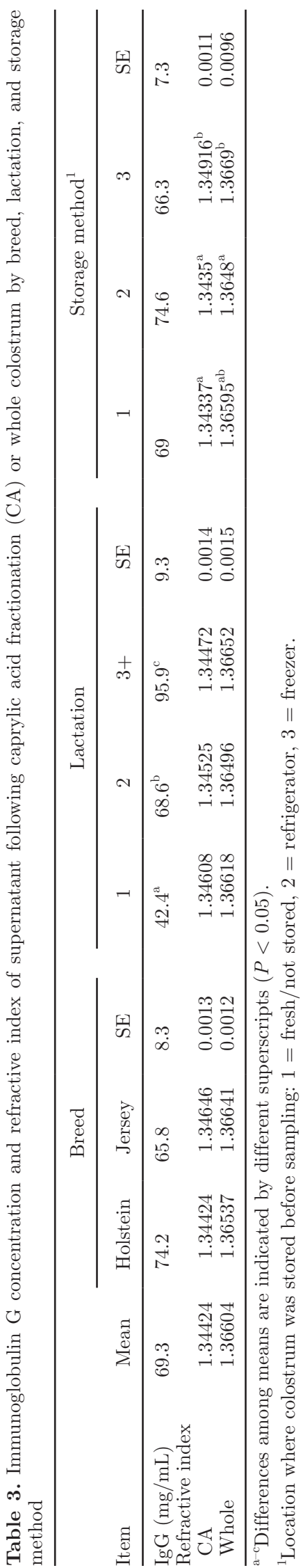

Journal of Dairy Science Vol. 95 No. 7, 2012
Data from the current study suggest that breed, lactation, nutrient composition, and bacterial contamination had minimal effects on the relationship between $\mathrm{nDf}$ and $\operatorname{IgG}$ concentration. However, storage and the number of FT cycles before analysis significantly affected this relationship. When $\mathrm{nDf}$ was measured with fresh colostrum or with a maximum of one FT cycle, correlation coefficients were similar to those seen in the development of the test in the laboratory. Whole MC samples collected fresh and analyzed by refractometry before freezing resulted in a stronger relationship than has been reported using \%Brix values (Chigerwe, 2008; Bielmann et al., 2010); however, whole MC samples collected fresh and not analyzed until after one FT cycle resulted in a weaker relationship between $\mathrm{nD}$ and RID, which was similar to previously reported data (Bielmann et al., 2010).

Samples that were collected fresh but frozen before analysis, as well as refrigerated and frozen samples, had a weaker relationship between $\mathrm{nD}$ (both $\mathrm{nDf}$ and $\mathrm{nDw}$ ) and IgG. The process of freezing, storing, thawing, and potentially refreezing can alter biological samples (Farrant, 1980) and result in different SCC (Barkema et al., 1997) estimates and ELISA results (Vanderstichel et al., 2010) compared with the original, fresh samples. The temperature at which milk samples are stored and the thawing process are important for accurate analysis of components, especially SCC and pathogens (Farrant, 1980). Insufficient cell shrinkage during cooling causes the formation of excessive amounts of intracellular ice that may damage cells (Farrant, 1980). Because milk is not a pure solvent that freezes entirely in one step, cells contained within the milk are exposed to extracellular ice, an increased concentration of extracellular solutes, and consequently an increased osmolality, which tends to withdraw water down an osmotic gradient (Farrant, 1980).

Storage and handling of dairy products after harvest and before consumption can alter their physical, nutritional, and bacterial characteristics. Lipolysis in milk and $\mathrm{MC}$ is derived from 2 enzymatic processes: natural milk lipase (secreted by the animal) and microbial lipases (Antonelli et al., 2002). Natural lipase activity depends on the time elapsed between milking and processing or feeding, temperature of storage, and handling of milk. When micelles are broken down, the lipids become more available for enzyme attack. Microbial lipases are produced by psychrotrophic bacteria, which are able to grow in milk during storage at $4^{\circ} \mathrm{C}$ (Law et al., 1976). Lipoprotein lipase in MC is present bound to the casein micelle and in the milk serum. The unbound lipase is more effective in promoting lipolysis than the casein-bound lipase (Anderson, 1982). If microbial lipases were present in our samples, lipolysis may have 
Table 4. Overall sample means for IgG, nutrients, and bacterial contamination

\begin{tabular}{lcrrrr}
\hline Item & $\begin{array}{c}\text { Samples } \\
\text { (no.) }\end{array}$ & Mean & SD & Minimum & Maximum \\
\hline IgG $(\mathrm{mg} / \mathrm{mL})$ & 827 & 68.8 & 32.9 & $<1.8$ & 200.2 \\
Fat (\%) & 531 & 5.6 & 3.2 & 1.0 & 21.7 \\
Protein (\%) & 542 & 12.7 & 3.3 & 2.6 & 20.5 \\
Lactose (\%) & 538 & 2.9 & 0.5 & 1.2 & 4.6 \\
Other solids (\%) & 544 & 4.3 & 0.5 & 1.1 & 8.8 \\
Total solids (\%) & 496 & 22.6 & 4.7 & 1.7 & 33.1 \\
SCC (log $10 \mathrm{cfu} / \mathrm{mL})$ & 548 & 5.9 & 0.8 & 3.8 & 7.3 \\
Total plate count $\left(\log _{10} \mathrm{cfu} / \mathrm{mL}\right.$ & 548 & 4.9 & 0.9 & 3.0 & 6.8 \\
\hline
\end{tabular}

Table 5. Effect of storage method before collection on the relationship between IgG and refractive index of caprylic acid fractionation supernatant $(\mathrm{nDf})$ or whole colostrum $(\mathrm{nDw})$

\begin{tabular}{lccccccc}
\hline & & \multicolumn{2}{c}{$\operatorname{IgG} \times \mathrm{nDf}$} & & \multicolumn{2}{c}{$\mathrm{IgG} \times \mathrm{nDw}$} \\
\cline { 3 - 4 } \cline { 6 - 7 } Storage & $\begin{array}{c}\text { Samples } \\
\text { (no.) }\end{array}$ & $\mathrm{r}$ & & $P$-value & & $\mathrm{r}$ & $P$-value \\
\hline Fresh & 196 & & 0.69 & $<0.0001$ & & 0.71 & $<0.0001$ \\
Refrigerated & 152 & & 0.50 & $<0.0001$ & & 0.56 & $<0.0001$ \\
Frozen & 479 & & 0.56 & $<0.0001$ & & 0.47 & $<0.0001$ \\
\hline
\end{tabular}

Table 6. Relationship between IgG and refractive index of whole colostrum ( $\mathrm{nDw}$ ) or supernatant following caprylic acid fractionation (nDf) across storage groups and freeze-thaw cycles

\begin{tabular}{|c|c|c|c|c|c|c|c|c|c|}
\hline \multirow[b]{2}{*}{ Category $^{1}$} & \multicolumn{3}{|c|}{$\mathrm{IgG} \times \mathrm{nDf}$} & \multicolumn{3}{|c|}{$\mathrm{IgG} \times \mathrm{nDw}$} & \multicolumn{3}{|c|}{$\begin{array}{l}\text { Times frozen } \\
\text { before analysis }{ }^{2}\end{array}$} \\
\hline & $\mathrm{n}$ & $\mathrm{r}$ & $P$-value & $\mathrm{n}$ & $\mathrm{r}$ & $P$-value & $\mathrm{nDf}$ & $\mathrm{nDw}$ & $\mathrm{RID}^{3}$ \\
\hline Fresh 1 & 34 & 0.94 & $<0.0001$ & 128 & 0.78 & $<0.0001$ & 1 & 0 & 1 \\
\hline Fresh 2 & 47 & 0.09 & 0.0397 & 25 & 0.01 & 0.6838 & 2 & 1 & 2 \\
\hline Refrigerated 0 & 75 & 0.43 & $<0.0001$ & 29 & 0.41 & 0.026 & 0 & 0 & 1 \\
\hline Frozen 2 & 66 & 0.72 & $<0.0001$ & 138 & 0.80 & $<0.0003$ & 2 & 1 & 2 \\
\hline Frozen 3 & 295 & 0.37 & $<0.0001$ & 296 & 0.69 & $<0.0004$ & 3 & 1 & 3 \\
\hline
\end{tabular}

${ }^{1}$ Fresh $=$ maternal colostrum $(\mathrm{MC})$ was not refrigerated or frozen before collection; Refrigerated $=$ MC was collected from a refrigerator; Frozen $=\mathrm{MC}$ collected from previously frozen before collection.

${ }^{2}$ Numbers indicate the number of times the collected sample was frozen prior to analysis of nDf, nDw, or RID.

${ }^{3}$ Radial immunodiffusion.

Table 7. Diagnostic test characteristics ${ }^{1}$ for the digital refractometer measuring supernatant following the caprylic acid fractionation or whole colostrum compared with IgG determined by radial immunodiffusion assay

\begin{tabular}{|c|c|c|c|c|c|}
\hline \multirow[b]{2}{*}{ Item } & \multirow[b]{2}{*}{ Cut-point } & \multicolumn{4}{|c|}{ Test characteristic (\%) } \\
\hline & & Sensitivity & Specificity & PPV & NPV \\
\hline CA supernatant & $1.33987^{2}$ & 98.6 & 22.0 & 75.3 & 86.4 \\
\hline Whole colostrum & $1.35966^{3}$ & 93.6 & 92.2 & 96.7 & 85.6 \\
\hline
\end{tabular}




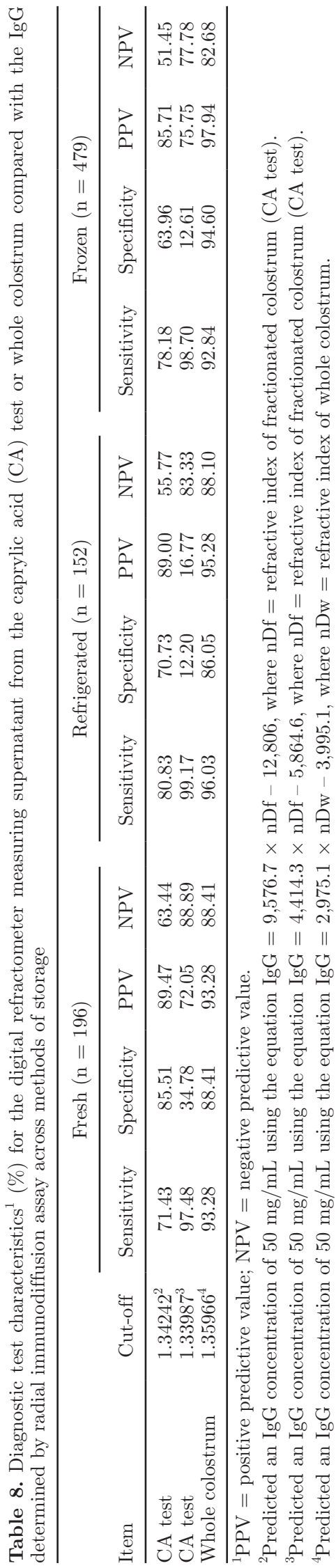

Journal of Dairy Science Vol. 95 No. 7, 2012 occurred during storage. The change in FA composition may have affected the ability of the acetic acid to bind fat and CA to precipitate non-IgG proteins. Nutrient and bacterial analysis were only completed once, and individual FA were not analyzed in this study.

\section{Diagnostic Test Characteristics}

To quickly determine if $\mathrm{MC}$ is of sufficiently high quality to feed to calves, we determined the $\mathrm{nD}$ cut-points that would correspond to IgG concentrations $>50 \mathrm{mg} /$ $\mathrm{mL}$. Diagnostic test characteristics were established for $\mathrm{CA}$ test $\mathrm{nD}$ and whole $\mathrm{MC} \mathrm{nD}$ based on the entire data set, storage method, and FT cycles to determine if different cut-points were needed for multiple variants. Maximizing the sensitivity of a test allows for the smallest number of samples being inaccurately identified as $>50 \mathrm{mg} / \mathrm{mL}$. This prevents the feeding or storage of $\mathrm{MC}$ with insufficient $\operatorname{IgG}(<50 \mathrm{mg} / \mathrm{mL})$, making sensitivity of an MC quality test more important than specificity. Use of cut-point values below optimal would increase the amount of $\mathrm{MC}$ classified as adequate, but would increase the chances that inadequate $\mathrm{MC}$ would be classified as adequate. Using cut-points greater than optimal would decrease the chances of inaccurately classifying poor MC as adequate; however, some adequate MC may be incorrectly classified as inadequate.

The sensitivity (93.58\%) and specificity (92.24\%) for whole MC (no CA fractionation) in this data set suggest that a cut-point of 1.35966 , determined from the relationship between $\operatorname{IgG}$ and $\mathrm{nDw}$, is highly reliable for identifying quality MC. This cut-point provided high sensitivity and specificity across breed, lactations, and storage methods. This confirms that parity, breed, and storage do not affect the accuracy of $\mathrm{nD}$ in determining whether whole $\mathrm{MC}$ is adequate.

Throughout this study, we assumed that the RID analysis for IgG was accurate and not affected by breed, lactation, storage method, nutrient composition, or bacterial contamination of MC. Fleenor and Stott (1981) commented that RID analysis has not been investigated thoroughly to determine sources of potential error. Although laboratory analysis using RID continues to be the industry standard to determine IgG concentration, limited information is available as to factors that affect the accuracy of RID kits. Our study did not examine whether the factors affecting the relationship between RID-determined IgG and refractometry-estimated IgG were also affecting the accuracy of the RID kits.

\section{CONCLUSIONS}

Breed, lactation, and nutrient composition do not affect the accuracy of the CA test or the refractive index 
Table 9. Diagnostic test characteristics ${ }^{1}(\%)$ for the digital refractometer measuring supernatant from the caprylic acid (CA) test or whole colostrum compared with the IgG determined by radial immunodiffusion assay for fresh 0 and fresh 1 samples $^{2}$

\begin{tabular}{lcccccc}
\hline Item & Cut-off & Sensitivity & Specificity & PPV & NPV & $\begin{array}{c}\text { Samples } \\
\text { (no.) }\end{array}$ \\
\hline CA test & $1.34239^{3}$ & 79.7 & 92.5 & 92.6 & 79.5 & 146 \\
Whole colostrum & $1.36175^{4}$ & 93.28 & 88.41 & 93.28 & 88.41 & 152 \\
\hline
\end{tabular}

${ }^{1} \mathrm{PPV}=$ positive predictive value; $\mathrm{NPV}=$ negative predictive value.

${ }^{2}$ Fresh $0=$ samples collected fresh and frozen once prior to RID analysis; fresh $1=$ samples collected fresh and frozen once prior to analysis by CA test.

${ }^{3}$ Correlates to an $\mathrm{IgG}$ concentration of $50 \mathrm{mg} / \mathrm{mL}$ using the equation $\operatorname{IgG}=8,735.9 \times \mathrm{nDf}-11,677$, where $\mathrm{nDf}$ $=$ refractive index of fractionated colostrum (CA test).

${ }^{4}$ Correlates to an IgG concentration of $50 \mathrm{mg} / \mathrm{mL}$ using the equation $\operatorname{IgG}=3,224.9 \times \mathrm{nDw}-4,338.3$, where $\mathrm{nDw}=$ refractive index of whole colostrum.

of whole colostrum when estimating IgG concentration in MC. The storage of MC does affect the accuracy of both tests. When $\mathrm{MC}$ is analyzed fresh, the $\mathrm{CA}$ test and refractive index of whole MC provide rapid and accurate methods to determine IgG concentration. Both tests have lower accuracy when samples are refrigerated or frozen before analysis. The refractive index of fresh $\mathrm{MC}$ provides producers with an easy, rapid, and accurate method to determine IgG concentration of MC.

\section{REFERENCES}

Anderson, M. 1982. Factors affecting the distribution of lipoprotein lipase activity between serum and casein micelles in bovine milk. J. Dairy Res. 49:51-59.

Antonelli, M. L., R. Curini, D. Scricciolo, and G. Vinci. 2002. Determination of free fatty acids and lipase activity in milk: Quality and storage markers. Talanta 58:561-568.

Barkema, H. A., J. Van Der Schans, Y. H. Schukken, A. L. W. De Gee, T. J. G. M. Lam, and G. Benedictus. 1997. Effect of freezing on somatic cell count of quarter milk samples as determined by a Fossomatic electronic cell counter. J. Dairy Sci. 80:422-426.

Bergmann-Leitner, E. S., R. M. Mease, E. H. Duncan, F. Khan, J. Waitumbi, and E. Angov. 2008. Evaluation of immunoglobulin purification methods and their impact on quality and yield of antigen specific antibodies. Malar. J. 7:129-138.

Bielmann, V., J. Gillan, N. R. Perkins, A. L. Skidmore, S. Godden, and K. E. Leslie. 2010. An evaluation of brix refractometry instruments for measurement of colostrum quality in dairy cattle. J. Dairy Sci. 93:3713-3721.

Calloway, C. D., J. W. Tyler, R. K. Tessman, D. Hostetler, and J. Holle. 2002. Comparison of refractometers and test endpoints in the measurement of serum protein concentration to assess passive transfer status in calves. J. Am. Vet. Med. Assoc. 221:1605-1608.

Chavatte, P., F. Clément, R. Cash, and J. F. Grongnet. 1998. Field determination of colostrum quality by using a novel, practical method. AAEP Proc. 44:206-209.

Chigerwe, M., J. W. Tyler, J. R. Middleton, J. N. Spain, J. S. Dill, and B. J. Steevens. 2008. Comparison of four methods to assess colostral IgG concentration in dairy cows. J. Am. Vet. Med. Assoc. 233:761-766.

Farrant, J. 1980. Freeze-thaw injury in living cells. Int. J. Refrig. 3:191-195.

Fleenor, W. A., and G. H. Stott. 1980. Hydrometer test for estimation of immunoglobulin concentration in bovine colostrum. J. Dairy Sci. 63:973-977.
Fleenor, W. A., and G. H. Stott. 1981. Single radial immunodiffusion analysis for quantification of colostral immunoglobulin concentration. J. Dairy Sci. 64:740-747.

Foley, J. A., and D. E. Otterby. 1978. Availability, storage, treatment, composition and feeding value of surplus colostrum: A review. J. Dairy Sci. 61:1033-1060.

Grodzki, A. C., and E. Berenstein. 2010. Antibody purification: Ammonium sulfate fractionation or gel filtration. Chapter 3 in Immunocytochemical Methods and Protocols. Methods in Molecular Biology. Humana Press, Totowa, NJ.

Guidry, A. J., and C. N. O'Brien. 1996. A method for measuring specific antibodies in bovine lacteal secretions during the nonlactating period. J. Dairy Sci. 79:846-850.

Gulliksen, S. M., K. I. Lie, L. Solverod, and O. Osteras. 2008. Risk factors associated with colostrum quality in Norwegian dairy cows. J. Dairy Sci. 91:704-712.

Jaster, E. H. 2005. Evaluation of quality, quantity, and timing of colostrum feeding on immunoglobulin $\mathrm{G}_{1}$ absorption in Jersey calves. J. Dairy Sci. 88:296-302.

Kume, S., and A. Tanabe. 1993. Effect of parity on colostral mineral concentrations of Holstein cows and value of colostrum as a mineral source for newborn calves. J. Dairy Sci. 76:1654-1660.

Law, B. A., M. E. Sharpe, and H. R. Chapman. 1976. The effect of lipolytic gram-negative psychrotrophs in the development of rancidity in cheddar cheese. J. Dairy Res. 43:459-468.

Lecce, J. G. 1972. Selective absorption of macromolecules into intestinal epithelium and blood by neonatal mice. J. Nutr. 102:69-75.

Lecce, J. G. 1984. Absorption of macromolecules by mammalian intestinal epithelium. Pages 33-44 in Intestinal Toxicology. Raven Press, New York, NY.

ICUMSA. 2009. Specification and Standard SPS-3: Refractometry and tables. International Commission for Uniform Methods of Sugar Analysis (ICUMSA) Methods Book. Bartens, Berlin, Germany.

Mechor, G. D., Y. T. Grőhn, L. R. McDowell, and R. J. Van Saun. 1992. Specific gravity of bovine colostrum immunoglobulins as affected by temperature and colostrum composition. J. Dairy Sci. 75:3131-3135.

Molla, A. 1980. Estimation of bovine colostral immunoglobulins by refractometry. Vet. Rec. 107:35-36.

Moore, D. A., J. Taylor, M. L. Hartman, and W. M. Sischo. 2009. Quality assessment of waste milk at a calf ranch. J. Dairy Sci. 92:3503-3509.

Morin, D. E., P. D. Constable, F. P. Maunsell, and G. C. McCoy. 2001. Factors associated with colostral specific gravity in dairy cows. J. Dairy Sci. 84:937-943.

Muller, L. D., and D. K. Ellinger. 1981. Colostral immunoglobulin concentrations among breeds of dairy cattle. J. Dairy Sci. 64:17271730.

NAHMS (National Animal Health Monitoring System). 1996. Part II changes in the U.S. dairy industry: 1991-1996. USDA:APHIS:VS, Fort Collins, CO. 
NAHMS (National Animal Health Monitoring System). 2007. Heifer calf and management practices on U.S. dairy operations. USDA:APHIS:VS:CEAH, Fort Collins, CO.

Nocek, J. E., D. G. Braund, and R. G. Warner. 1984. Influence of neonatal colostrum administration, immunoglobulin, and continued feeding of colostrum on calf gain, health and serum proteins. J. Dairy Sci. 67:319-333.

Pácha, J. 2000. Development of intestinal transport function in mammals. Physiol. Rev. 80:1633-1667.

Quigley, J. D., K. R. Martin, H. H. Dowlen, L. B. Wallis, and K. Lamar. 1994. Immunoglobulin concentration, specific gravity and nitrogen factions of colostrum from Jersey cattle. J. Dairy Sci. $77: 264-269$.

Smith, E. L. 1948. The isolation and properties of the immune proteins of bovine milk and colostrum and their role in immunity: A review. J. Dairy Sci. 31:127-138.
Smith, V. R., R. E. Reed, and E. S. Erwin. 1964. Relation of physiological age to intestinal permeability in the bovine. J. Dairy Sci 47:923-924.

Stott, G. H., and A. Fellah. 1983. Colostral immunoglobulin absorption linearly related to concentration for calves. J. Dairy Sci 66:1319-1328.

Vanderstichel, R., I. Dohoo, and H. Stryhn. 2010. The impact of milk handling procedures on Ostertagia ostertagi antibody ELISA test results. Vet. Parasitol. 169:204-208.

Wehr, M., ed. 2004. Standard Methods for the Examination of Dairy Products. 17th ed. Am. Public Health Assoc., Washington, DC. 